\title{
Expendables for Whom: Terry Crews and the Erasure of Black Male Victims of Sexual Assault and Rape
}

\section{Tommy J. Curry}

To cite this article: Tommy J. Curry (2019) Expendables for Whom: Terry Crews and the Erasure of Black Male Victims of Sexual Assault and Rape, Women's Studies in Communication, 42:3, 287-307, DOI: $10.1080 / 07491409.2019 .1641874$

To link to this article: https://doi.org/10.1080/07491409.2019.1641874

曲 Published online: 30 Jul 2019.

Submit your article to this journal $\widetilde{ }$

Џلll Article views: 192

Q View related articles $\widetilde{ }$

View Crossmark data $\nearrow$

Citing articles: 1 View citing articles 


\title{
Expendables for Whom: Terry Crews and the Erasure of Black Male Victims of Sexual Assault and Rape
}

\author{
Tommy J. Curry
}

School of Philosophy, Psychology, and Language Sciences, University of Edinburgh, Edinburgh, Scotland, United Kingdom

\begin{abstract}
The sexual assault of Terry Crews by Adam Venit raises all sorts of questions about the nature of sexual violence and our reluctance to see Black men as victims of sexual assault in the United States. Despite a history of Black men and boys being raped by White men and women, there is no effort to connect the centuries-long record of sexual violence against Black males to the sexual victimization of Black men and boys currently. This article analyzes the language, history, and stereotypes deployed in our understanding of Terry Crews's victimization, even those he uses to describe himself, to better situate and describe the vulnerability of Black men and boys to sexual violence in the United States.
\end{abstract}

\section{KEYWORDS}

Black male studies; Black male victims of rape and sexual violence; Black male vulnerability; Terry

Crews; racism

On October 10, 2017, Terry Crews-a Black male actor and former professional athlete in the National Football League-announced on Twitter that he was a victim of sexual assault at the hands of well-known Hollywood executive Adam Venit: "My wife n I were at a Hollywood function last year in a high level Hollywood executive came over 2 me and groped my privates. This whole thing with Harvey Weinstein is giving me PTSD. Why? Because this kind of thing happened to ME” (Crews, 2017b).

When Crews first announced himself as a survivor of sexual assault and a victim of sexual violence, many of the responses on Twitter blamed him for not defending himself from the assault and knocking the attacker out. Crews explained that Black men are not able to defend themselves from violence even when they are attacked by a weaker aggressor. If he did defend himself with violence from the groping of Venit, " 240 lbs. Black Man stomps out Hollywood Honcho' would [have] be[en] the headline the next day" (Crews, 2017a). In a June testimony before the U.S. Senate to expand the sexual assault Survivors' Bill of Rights Act, Crews explained that

as a black man in America, you only have a few shots at success. You only have a few chances to make yourself a viable member of the community. I'm from Flint, Michigan. I have seen many, many young black men who were provoked into violence, and they were imprisoned or they were killed. And they're not here ... . My wife, for years, prepared me. She said: "If you ever get goaded, if you ever get prodded, if you ever get anyone trying to push you into any situation, don't do it, don't be violent." (Kelly, 2018, paras. 4-5)

CONTACT Tommy J. Curry, D.J.Curry@ed.ac.uk D Department of Philosophy, School of Philosophy, Psychology, and Language Sciences, University of Edinburgh, Dugald Stewart Building, 3 Charles Street, Edinburgh, Scotland, EH 8 9AD, United Kingdom.

(C) 2019 The Organization for Research on Women and Communication 
Crews, "as a Black man in America," explained to the senator that violence was not-is not-an option. No matter if he was defending himself from the sexual aggression of Venit, Crews would be framed, interpreted, seen by the public as the attacker. His physical size, skin color, and maleness made him the threat irrespective of the actual violence inflicted upon him. Black men are burdened by the threats others perceive them to be. Our belief that Black men are dangerous and in need of control and criminal sanction nullifies our ability to perceive them as victims of violence at the hands of other groups of men or even women.

Despite Crews's accusation against Venit being eerily similar to the stories and experiences of female victims of sexual harassment and assault shared under \#MeToo, it is clear that \#MeToo is unable to fully comprehend and incorporate Crew's vulnerability to sexual violence as a Black male. Crews has certainly been acknowledged to be a victim of Venit's toxic masculinity, but is Crews a victim because as a Black male he is vulnerable to sexual violence? Or is Mr. Crews a victim because he was victimized by a toxic male?

The increasing number of stories by male victims of sexual violence has spurred on a debate over the status of male victimization within \#MeToo. I believe Crews's narrative exposes some of the discursive limitations of how \#MeToo conceptualizes Black male victims of sexual assault and rape. While this article certainly builds from many of the concerns generally raised about male victims of sexual assault in \#MeToo, I am particularly concerned about the ways that some of the discussions utilize feminism and patriarchy as an intuitive marker that indicates who can be and who usually are victims of rape, sexual harassment, and sexual assault in this society. The erasure of Black male victims - specifically, their disproportionate sexual victimization in the United Statespersists unabated in the era of \#MeToo as female victims. Women's stories and narratives continue not only to displace but also to deny the prevalence of Black male sexual victimization at the hands of other men and women. This article is critical of the discursive formulations of \#MeToo asserting that men, specifically Black men, are primarily perpetrators of sexual violence and rarely victims of sexual violence.

Terry Crews's story has been accepted into \#MeToo based on his victimization at the hands of another man, not his position as an actual victim of sexual assault. I want to be clear about this point as it matters to how we think about and rhetorically situate Black males in conversations about rape and sexual violence. Crews's experience of sexual assault is not being discussed as evidence of the at-large vulnerability Black men have to being sexually assaulted, raped, or made to penetrate others. Crews's narrative has been almost singularly interpreted as him being a victim of toxic masculinity. Unlike the narratives of \#MeToo that emphasize women's vulnerability to sexual violence throughout U.S society, Crews is thought to simply be the victim of one man's desire; he is simply not thought of being part of a class vulnerable to sexual violence as a Black man. Crews's assault became more mainstream and part of \#MeToo as he adopted more of the discursive formulations of contemporary feminism (e.g., toxic masculinity, patriarchy, male privilege) and the "male as perpetrator" paradigm of \#MeToo. Even with Crews's acceptance within \#MeToo, U.S. society is still reticent to acknowledge the sexual vulnerability of Black men to rape, sexual assault, and sexual coercion.

Many scholars, activists, and gender theorists consider it inconceivable that Black men $(6.5 \%)$ in the United States experience contact sexual violence (which includes 
rape, being made to penetrate, sexual coercion, and unwanted sexual contact) as often as Black women $(5.8 \%)$ in a given year, or have rates of sexual victimization higher than White women (3.6\%) (Smith et al., 2017, pp. 18, 21, 28). Consequently, any data or evidence suggesting that Black men are victims of sexual violence or rape comparable to women are often rejected outright. While the National Crime Victimization Survey (NCVS) conducted by the U.S. Bureau of Justice Statistics (BJS) contains the most cited data on rape in the United States, its survey methodology has been criticized for not fully capturing women's experiences of victimization (Lynch, 1996) or the role of consent, because it emphasizes the individual's ability to identify his or her experience of rape as a crime (Groden, 2014). The Centers for Disease Control and Prevention (CDC) National Intimate Partner and Sexual Violence Survey (NISVS) is much more attuned to an individual's experience of sexual events and has consistently shown that men suffer comparable rates of sexual violence as women in the United States. According to Black et al. (2011), U.S. male victims of made-to-penetrate violence $(1,267,000)$ are similar to the number of women rape victims $(1,270,000)$ over a 12-month period (pp. 18-19). This statistic is largely ignored because it cuts against too many ingrained gender stereotypes concerning our popularly held assumptions about rape and the nature of patriarchy. However, wrestling with empirical data that may contradict established postulates is necessary to advance theory-especially theories about Black men and boys, who remain absent from our thinking about victims of sexual violence.

This article analyzes the assumptions directing interpretations of Mr. Crews's victimization to challenge and discredit the understanding of Black men as second-class victims of sexual violence and rape. In what follows, I argue that Crews's acceptance by \#MeToo is rooted in his confirmation of the dominant feminist view that men are primarily the perpetrators of sexual violence and women are almost solely victims, a position which is actually at odds with the views of Tarana Burke, the original founder of Me Too. Then, I draw on Burke's understanding of \#MeToo as a movement that urges the United States to deal with the trauma of sexual violence against both men and women. Following Burke, academics would find an analysis of sexual assault, rape, and violence that problematizes the dominant male as perpetrator view asserted by many \#MeToo activists, as well as Crews himself. Specifically, I articulate a different lens through which to perceive the vulnerability of Black men generally and historicize the sexual assault against Crews. The history of Black men's rape and the data showing Black males as vulnerable to sexual violence should change how we conceptualize the risk Black men and boys have to sexual violence in the United States. In the final section, I argue that the dangerous racist and gendered stereotyping of Black men as criminals, deviants, and sexual predators is a powerful and enduring paradigm that essentializes and reifies racialized men as invulnerable to sexual violence.

\section{Terry Crews's recognition as a victim of sexual assault in \#MeToo}

\#MeToo rose to popularity in October 2017 when Alyssa Milano tweeted the hashtag to bring awareness to the problem of sexual harassment and assault in society. Her audience and message were specifically geared toward the sexual vulnerability of women. In her first tweet on \#MeToo, Milano (2017) wrote: "If you've been sexually harassed or 
assaulted write 'me too' as a reply to this tweet." According to Twitter, "in less than 24 hours, 4.7 million people around the world ... engaged in the \#MeToo conversation, with more than 12 million posts, comments and reactions" (Santiago and Criss, 2017, para. 32). While \#MeToo certainly captured the experiences of many rich White actresses, entertainers, and celebrities, Milano actually appropriated the term "me too" from Tarana Burke, a sexual assault survivor and director of the Brooklyn-based Girls for Gender Equity, who created Me Too in 2006 to empower young women of color (Santiago and Criss, 2017, para. 4). Burke has dedicated her life to helping female victims of sexual assault and abuse. Unlike the symbolic representation of \#MeToo offered by the positioning of prominent (and mostly White) women-The Silence Breakers-as Time's 2017 Person of the Year, Burke has suggested that discursive innovation should take a backseat to the more real-world agenda of helping actual victims. As Burke said, "We don't need another 'thing.' If we keep on 'making statements' and not really doing the work, we are going to be in trouble" (Walden, 2018, para. 1). Burke's position demands the public help, hear, and heal victims.

For many people, \#MeToo should be a feminist moment exclusively focused on female victimization and male perpetration (Haider, 2019; Mack \& McCann, 2018). Over the past several months, more stories from male victims and the recent revelation of Asia Argento as the (statutory) rapist of a male teen has troubled many of the core assumptions of this moment and complicates the agreed-upon narrative that women are primarily victims to men, not perpetrators of violence toward men (Weiss, 2018). The act of sexual perpetration against men and boys has caused some debate as to the focus, theory, and political commitments of the \#MeToo movement (Bowen, 2018). Various publications and critics (Bump, 2018; Chandler, 2018; Levin, 2017) have pointed out that while women are often victims of sexual harassment and assault, there are also a substantial number of male victims of sexual assault and rape that remain unheard, unseen, and silenced by the rhetoric and political ideations of \#MeToo.

Remarking on the failure of the male victims of sexual assault to receive serious attention by the movement, Klee (2018) drew attention to how male victims of sexual assault like Crews and Brendan Fraser were ridiculed by having their sexual assaults lessened to jokes and playful pokes about others groping their bodies. Such ridicule toward male victims' reports is why more male victims do not come forward and share their stories. Klee (2018) wrote, "This is how we victim-blame men: not for drinking too much or wearing the wrong clothes or seeking salacious fame, but for not playing along when another guy crosses a line. The villains here invoke the same fraternity of silence that gaslights and suppresses female victims" (para. 8).

Often, male victims of sexual assault are told to ignore it, give it a pass, or interpret their assault as nothing more than a different interpretation or misguided intention of their harasser. However, appeasing this advice would simply reinforce "the toxic assumption that men are invulnerable to these attacks - that to be a victim is, essentially, to be a woman" (Klee, 2018, para. 8). Some commentators such as Norton (2017) have suggested that the recognition of male victims within \#MeToo is almost impossible if not paradoxical in nature. He explained:

Male victim rape and sexual assault are clearly neglected and under-reported, so \#metoo gave some men a safe space and enough momentum to share their experiences. The 
paradox is this: if women experienced \#metoo as a safe space, free from the interruption and judgment, then some of them-rightfully-didn't want perceived male intrusion. Given the lack of information, shaming, and beliefs towards men vis-a-vis sexual violence (not as affected by rape, cannot be raped, must have enjoyed it, etc.), it becomes exponentially more difficult for men to speak out. (para. 20)

Crews's story of victimization thereby occupies a somewhat peculiar place in the unfolding of \#MeToo as a moment and cultural narrative. While Crews's case is a specific example of the numerous male victims that have themselves been tormented by the trauma of their sexual assaults, the death of Chester Bennington or the years of therapy Tyler Perry needed to deal with his abuse have not been centered in any noticeable way in the discourse and representations of the \#MeToo movement (Crary, 2018). As one male survivor said:

Because the movement happened to get its start with women only, in a way it furthers my loneliness as a past victim .... Men are historically considered the bad guys. If some men abuse women, then we all are abusers ourselves ... so therefore when it comes to our being abused, we deserve it. (Crary, 2018, paras. 4-5)

Because men are viewed primarily as perpetrators of violence and abuse, they are rarely understood to be victims and, consequently, can never be the leading subject of conversations about rape, sexual harassment, or sexual victimization.

Crews seems to rationalize his story as one of survival demonstrating the violence of toxic masculinity. Crews views \#MeToo as a dialogue accommodating all victims' experiences equally. However, Crews's optimism seems to be at odds with reality-or the financial underpinnings of \#MeToo. In an interview with Deadline in January 2018, Crews was asked about his lawsuit against Adam Venit and the Time's Up legal defense fund for victims of sexual assault and abuse. He replied:

this is my concern, symbolic victories are no good. People tend to get satisfied by symbolic victories. I mean, when you're talking about Time's Up, hey, Time's Up is one of the greatest ideas of all time and I'm standing with these women. I am with it, I could not be more supportive, but when you let William Morris just put in \$1.5 million dollars, pledged that to Time's Up, and my assailant still works there, I was hung out to dry, and now they're pledging this money in an attempt to buy your justice. To me, it's arrogance on top of arrogance. (Patten, 2018, para. 10)

In March 2018, Crews would find out that his lawsuit was rejected by the Los Angeles district attorney (Messer and Ghebremedhin, 2018). For filing a lawsuit against William Morris Endeavor (WME) Entertainment, Crews was eliminated from The Expendables movie franchise. Crews is now unable to take legal action against his assailant and has lost earnings from going public with his abuse.

Crews has been very clear to the public that he understood himself to be powerless when Venit sexually assaulted him. Crews's experience of sexual assault, specifically his inability to defend himself from the sexual aggression of Venit, was communicated as an effect of the fear others have of his Black male body. In June 2018, Crews explained to a Senate Judiciary Committee for the Survivors' Bill of Rights Act how anti-Black misandry, or the fear and hatred the United States has toward Black men, made him vulnerable to Venit's violence. Crews said, "Just imagine, if I had done something like that to his wife, would I get a pass? Or if he had done that and just imagine if I hit 
him back, would I have a career? No way. No way. That's the arrogance" (Patten, 2018, para. 12).

The inability of the United States to see a muscular Black man as a real victim of sexual violence hit Crews hard in the following months when it became obvious that he had no social capital or narrative of Black male sexual victimization that would mobilize others to act on his behalf. Unlike the female victims of \#MeToo, his accusation alone was not powerful enough to remove his assailant from his job or force WME to sanction Venit in any serious way. As a Black man accusing a White man of sexual assault, his body and vulnerability was not sacred enough to destroy Venit's career, much less get him fired. Remember, in other cases that were not part of \#MeToo but borrowed its cultural prominence, such as the anonymous letter concerning a date with Aziz Ansari (Way, 2018), the accusation (by a White woman) alone was enough to cancel his Netflix series and seriously endanger his career (Chang and O’Neill, 2018). Crews had to launch a civil suit against Venit and WME to get Venit to resign and WME to institute policies against sexual harassment (Clark, 2018).

How does Crews explain this tension (being a second-class victim, so to speak) between his sexual victimization, his racial vulnerability, and his commitment to women's issues as framed by \#MeToo? At a personal level, Crews has interpreted his struggle as similar to that of Frederick Douglass, who according to Crews "fought just as hard for women's suffrage as he did for the abolishment of slavery. I mean, just as hard. Once the Emancipation Proclamation happened he switched right over into women's suffrage" (Patten, 2018, para. 27). There is, of course, a history here that needs some nuance, but this really shows how Crews sees himself and his feminist politics aligning with the goals of \#MeToo, at least in theory. Materially, however, there seem to be obvious differences between his story of victimization and that of (mostly) White women. In my view, Crews knew that as a heterosexual Black male his story would never get public attention unless he could become part of \#MeToo. This need to be incorporated dictated the change in the language he utilized and the rise in the popularity of his story with the public. Having realized the lack of empathy he received as a Black male victim, he became an even more adamant and outspoken feminist ally and critic of toxic masculinity.

Despite the proliferation of discursive formulations designed to convey the intrasubjective experiencing of violence and the imposition of external ideological and structural forces on gendered bodies, there is a conspicuous lack of language that conveys the sexual vulnerability and victimization of men-specifically Black men-in our society. The sexual victimization of Crews resonated with \#MeToo to the extent that he was a victim of sexual assault by another male perpetrator and an ally of women. I can find no editorials or mainstream periodicals that point to the sexual assault of Crews as an example of the sexual violence Black males experience in U.S. society on the whole, as young men and children or at the hands of police. Whereas female victims of sexual assault and sexual harassment indicate a pervasive threat to women in the United States, Crews's story is individualized and particular to his person.

Increasingly, Crews has used a personalized language of victimization when he discusses his past participation in the cult of masculinity and the need for "men to hold other men accountable" for the victimization of other men and women. While he 
emphasizes the problem of masculinity, Crews's commentary elides a larger point about the broader cultural phenomenon of Black male sexual victimization and abuse. In recent months, his language describing sexual victimization has focused on the dangers of toxic masculinity, patriarchy, and female objectification (Santi, 2018). At the ninth annual Women in the World Summit, Crews explained:

Masculinity can be a cult, and when I say cult, it is no different than David Koresh. It's no
different than Jim Jones ... Y You know, the best example is slavery. It's when slaves were
yelling, "Oh my god. I am being beaten and hurt." The master would look at them like I
don't understand what you are saying... . It's almost like there is this disconnect, like they
won't see pain. There's a lack of empathy, and this is what happens with men and women.
Men who are in this cult, you can say as a woman-they talk, but that guy is not looking
at you as all the way human. And this is where you have to understand there is a
humanity issue here. You are like, "Why don't you hear me? Why don't you see my
feelings?" And they are like "You are not all the way human. You are here for me."
(Women in the World, 2018)

Crews's embrace of this particular narrative suggests that \#MeToo still lacks a language to describe and center the abuse of racialized men next to women generally. Black men have higher rates of sexual victimization than White women in the United States. If masculinity is, in fact, a cult, which some White hegemonic iterations of it certainly are, then what conceptualization of male vulnerability does Crews have to explain why women are the majority of the perpetrators of sexual violence against men when we consider men reporting being made to penetrate, sexual coercion, and unwanted sexual contact (Smith et al., 2017, p. 32)? Crews makes it a point to account for the violence inflicted upon him by Venit, but in doing so he has continued to offer a narrow understanding of sexual violence and rape that focuses more on male perpetration than male victimization.

Since early 2019, Crews has become even more outspoken concerning the topic of Black masculinity and its relationship to toxicity and violence. Referencing an online article published in The Root titled "Straight Black Men Are the White People of the Black Race" (Young, 2017), Crews responded that the idea that Black men are the White men of the Black race is "thought provoking" (2019b) and evident given the rates of domestic abuse and his experience with his father (2019a). A far cry from his initial efforts to recognize the victimization of Black men by sexual abuse, Crews suggested that the issue requiring the most attention is Black men's violence against women as sexual predators. The article shared by Crews has warranted replies by both activists and academics (Moore, 2018; Curry \& Curry, 2018). According to the article's author, Damon Young (2017), Black men "are the ones who get the biggest seat at the table and the biggest piece of chicken at the table despite making the smallest contribution to the meal" (para. 3). Following the trope that Black men do not provide for families or contribute any meaningful contribution to Black family life, Young continues that Black men are not only derelict in the duties of family but also dangerous. He writes, "And nowhere is this more evident than when considering the collective danger we pose to black women and our collective lack of willingness to accept and make amends for that truth" (para. 4).

Alongside Young's essay, Crews's rhetoric emphasizing the danger of Black men to their communities and to Black women runs contrary to fact and impedes the 
ability of U.S. society to empathize with Black male victims of sexual violence given their alleged sexual threats as rapists and abusers. Crews endorsed the dominant language of patriarchal (toxic) masculinity to describe the dehumanization of women that pays little attention to the differences of power, privilege, or perpetration against women based on class location or perhaps the more historically salient feature of race. A closer look at the data concerning sexual assault and rape among Blacks in the United States offers vastly different a picture of Black males than Crews describes.

\section{Tarana Burke and other challenges to the dominant feminist paradigm of sexual victimization}

The debate over the inclusion of male victims within \#MeToo was the topic of many editorials at the end of 2018. In an article titled "If We Want Men to Be a Part of \#MeToo, We Have to Stop Gendering the Movement," Arceneaux (2018) wrote, "If we want men to be a part of the \#MeToo movement, we need to acknowledge that they too can be victims" (para. 4). Citing Burke, Arceneaux urged activists and victims alike to remember that this moment should be an analysis of power and not the inscription of gendered stereotypes that force male victims into silence (para. 11). Other articles such as Perry's (2018) “\#HimToo Should Be a Conversation About Male Victims of Sexual Assault" reported that "[t]oo often, even 'woke' men talk about fighting rape culture out of a need to protect the women in their lives" (para. 5). Referencing U.S. CDC data and the work of Lara Stemple, Perry (2018) concluded "that singular focus on women victims is misguided. We're all in this together" (para. 5). Unfortunately, data do not always persuade the masses. Activists and academics have been slow to adjust gender theories to reflect this reality. Burke, however, has been extremely clear that \#MeToo's core mission was to highlight sexual violence and the victims of that violence regardless of gender. As she stated in her TEDWomen talk, \#MeToo is "a movement about the 1 in 4 girls and the 1 in 6 boys who are sexually abused every year and who carry those wounds into adulthood" (Burke, 2018b). Recognizing male victims of sexual violence is central to Burke's vision of \#MeToo, even though she believes that such recognition runs counter to \#MeToo as currently conceptualized.

Burke's activism parts with academic feminism's account of sexual violence and perpetration in many ways. The dominant feminist account of sexual violence requires an understanding of males as perpetrators of sexual violence against female victims of sexual violence (Stemple, Flores, \& Meyer, 2017; Stemple \& Meyer, 2014; Cohen, 2014). In feminist analysis, rape and sexual violence occur as an outgrowth of ingrained sociocultural differences between the sexes (Brownmiller, 1975). MacKinnon (1979) similarly argued, "Aggression against those with less power is experienced as sexual pleasure" for men (p. 7). Following the male as perpetrator paradigm, feminist scholar Koss (1993) maintained:

Although consideration of male victims is within the scope of the legal statutes, it is important to restrict the term rape to instances where male victims were penetrated by offenders. It is inappropriate to consider as a rape victim a man who engages in unwanted sexual intercourse with a woman. (pp. 206-207)

Rape, as understood within the feminist analytic, applies only to or can include male victims of male perpetrators who forcibly penetrate their male bodies. A woman or 
other man making them penetrate their mouth or anus does not fall within the popular feminist paradigm. Cohen's (2014) book Male Rape Is a Feminist Issue: Feminism, Governmentality, and Male Rape similarly remarked that prevailing research by feminist academics has been driven by the idea that "rape is still the most gender specific of all crimes [where] 'only a man ... can be the actual perpetrator, only a woman the victim"' (p. 3). Much of the feminist research concerning male rape often suggests that "male rape is not prevalent overall, and that where it does occur, it only concerns homosexual communities" (Cohen, 2014, p. 17).

The inability of feminist frameworks to understand male vulnerability to rape by other men and by women to the same extent as women have to do with the construction of the woman as always vulnerable to sexual violence perpetrated by men. As Cohen (2014) explained,

[T] he reluctance to embrace male rape within the feminist rape model, as popularly conceived, is a result of the reluctance to adapt it, not an inability to do so. But this reluctance is understandable when the model itself is presented as so enmeshed with the legitimacy of the theoretical stance. One cannot revisit the feminist rape model without supposedly impinging on the feminist paradigm as a whole. (pp. 157-158)

Stemple and Meyer (2014) also note that the dominant feminist paradigm of sexual victimization deploys various myths that erase and lessen the suffering of male victims, preferring to see males primarily as sexual aggressors; they explain, "Because dominant feminist theory relies heavily on the idea that men use sexual aggression to subordinate women, findings perceived to conflict with this theory, such as female-perpetrated violence against men, are politically unpalatable" (pp. e19-e20).

The resistance of gender scholars to seriously consider the empirical findings showing males, particularly Black males, as having similar rates of sexual victimization as women not only impedes theory but creates a discursive barrier preventing the recognition and treatment of victimized men and boys. Even when men do report rape and sexual assault, they are rarely believed and are ridiculed within our current clinical institutions. This further silences males and increases the likelihood of negative behavioral and mental outcomes (Hohendorff, Habigzang, \& Koller, 2017).

This is not to say that all feminists are of the same mind about the sexual assault and rape of men in the United States. For example, feminist activist and writer Schroeder (2018) penned a powerful piece after Argento's rape of Jimmy Bennett recognizing that men were roughly half of all rape victims in the United States and are often forced into silence. However, dominant feminist frameworks and conceptualizations employed to interpret sexual violence erase male victimization generally and make Black male victimization to rape an impossibility to most academics and activists.

The case for Black men is far more complicated than merely encouraging recognition. Black males are stigmatized as violent brutes throughout multiple sectors of society. Among law enforcement, educational institutions, the at-large public, and even among many academics, Black men are theorized as terrors and popularly imagined to be pathological in nature. The dominant feminist theories coming out of the 1970s endorsed a pathological view of Black masculinity as violent and sexually aggressive. Following Wolfgang and Ferracuti (1967), Brownmiller (1975) actually argued that rape, 
specifically gang rape, was an attempt by Black men to project their manhood after desegregation and was a normal feature of the Negro male's subculture of violence (pp. 174-209). Brownmiller's account of Black masculinity plainly asserts that rape is a more normal, a more brutal, and a more prevalent practice among young Black males than among Whites (pp. 180-181). Many Black feminist accounts of Black masculinity actually extended Brownmiller's subculture of violence frame that interprets underclass (straight) Black males as particularly violent and beastlike-beings who take pleasure in the pain of others (Cooper, 2005; White, 2008; Garfield, 2010). In We Real Cool: Black Men and Masculinity, hooks (2004) argued:

Lots of young black men are walking around assuming a gangsta persona who have never and will never commit violent acts. Yet they collude with violent patriarchal culture by assuming this persona and perpetuating the negative racist/sexist stereotype that says "all black men are carriers of the violence we dread." Then there are the large numbers of underclass black males with no hope for the future who are actively violent. Added to this group are the black males who will never act violently outside the home, who do not commit crimes in the street, but who are, inside the home, in their private lives, abusive and violent. Overall the facts reveal that black males are more violent than ever before in this nation. And they are more likely to be violent toward another black person whom they deem less powerful. Much black male violence is directed toward females. Sexism and the assumption of the male right to dominate serves as the catalyst for this violence. (p. 52)

From this perspective, hooks maintained that Black males take pleasure in cultivating the image of violence and are satisfied by the fear it creates in others, especially the larger White society. "Young black males, particularly underclass males, often derive a sense of satisfaction from being able to create fear in others, particularly in white folks," wrote hooks (2004, p. 45). This analysis mirrors Wolfgang and Ferracuti's (1967) thesis in The Subculture of Violence, which argues "that in many lower-class communities violence is associated with masculinity and may be not only accepted but admired behavior" (p. 305). The existing frames used to interpret Black males are narrow and make violence endemic to this group. To date, not one feminist or Black feminist text has dedicated itself to understanding the rape of Black men beyond asserting that most rapes of Black men and boys are perpetrated by other males. This is an area that has been historically and systematically neglected in the current literature (Curry and Utley, 2018; Curry, 2017).

In 2012, the Department of Justice announced a change to the definition of rape, which took effect on January 1, 2013. The old definition of rape, originating in early20th-century case law, was "The carnal knowledge of a female forcibly and against her will” (Carbon, 2012, para. 1). This definition excluded the rape of males and various other offenses that would constitute sexual violence against a person. The new definition of rape adopted in the Uniform Crime Reporting (UCR) programs reporting system-"Penetration, no matter how slight, of the vagina or anus with any body part or object, or oral penetration by a sex organ of another person, without the consent of the victim"-attempts to capture male victims as well as other sexually coercive acts (Carbon, 2012, para 2).

For almost 100 years in the United States, rape was defined in such a way that only women could be victims of this crime. Now that society is grappling with male rape victims, 
there is a tendency to extend victimization to males but only insofar as they are victims to other men. We have not understood that males are susceptible to rape or that Black men are denied victimization altogether because of the historical stereotypes of them as rapists or hypersexual.

When considering the changes to the UCR, recent research has concluded that men comprise a significant number, if not half, of rape victims in the United States. According to Stemple and Meyer (2014), men and women in the United States report similar rates of nonconsensual sex in a 12-month period. Subsequent research by Stemple et al. (2017) also found surprising rates of female perpetration of sexual violence and rape against men. These findings, however, have not been widely publicized or accepted as fact because they disrupt many of the ideas we have about women in the West. In the United States, "[s]tereotypes about women, which reflect gender and heterosexist biases, include the notion that women are nurturing, submissive helpmates to men. The idea that women can be sexually manipulative, dominant, and even violent runs counter to these stereotypes" (Stemple et al., 2017, p. 303). The need to preserve the female subject as innocent and nonviolent, distinct from a male subject that is violent and driven by the will to dominate others, often accompanies the intuitive interpretations offered of sexual violence in U.S. society. To say that men perpetrate the majority of rape and sexual violence leaves undisturbed the general premise that most women do not commit sexual violence. While CDC data reports have shown that women constitute the majority of perpetrators in made-to-penetrate cases, sexual coercion, and unwanted sexual contact, our present framing of male rape victimization revolves around the visibility of the male perpetrator and toxic masculinity (Smith et al., 2017, p. 32). This is a significant obstacle in our attempts to understand Black male victims who experience higher rates of sexual violence than their White male counterparts.

Among Black Americans, we find similar sexual victimization rates between the sexes. According to the CDC's NISVS data, the incidence of rape and being made to penetrate were similar over a 12-month period. Black women reported 264,000 cases of rape, while Black men reported 272,000 cases of being made to penetrate (Smith et al., 2017, pp. 21, 28). When looking at 12-month prevalence, Black men and women both report near identical numbers of contact sexual violence. Black men report 865,000 cases and Black women report 849,000 cases of contact sexual violence (Smith et al., 2017, pp. 21, 28). Black men report higher rates of contact sexual violence $(6.5 \%)$ than White men (2.8\%) and White women (3.6\%), Hispanic men (5.2\%) and Hispanic women (4.3\%), and Black women (5.8\%). Despite the public availability of these data, the evidence of Black men's sexual victimization has created little societal impact or academic awareness of the sexual vulnerability of Black males in the United States. The most recent national data collected on unwanted sexual contact, rape, and being made to penetrate showed convincing evidence that sexual violence, assault, and coercion are not isolated to one sex, yet Black men remain on the periphery of conversations concerning sexual violence victimization and justice-seeking activism.

The little research published on sexual violence against Black men and boys shows that Black males are more likely than other groups of males (and some groups of females) to be victims of child sexual abuse, child physical abuse, statutory rape, and 
sexual coercion over the course their lives. Curry and Utley's (2018) study on Black male victims of sexual violence argued that "Black boys are often not understood to be socialized and maturing within spheres of sexual violence. Consequently, they are theorized as invulnerable to sexual coercion, sexual abuse, and statutory rape, despite their intimate proximity to these kinds of violence" (p. 234). Black children are particularly at risk for sexual abuse compared to their White counterparts, but what is often missed, given our current interpretive frames, is that Black males are more likely to be victims of completed and attempted sexual intercourse in these environments.

Black children are at higher risk of abuse than white children, particularly black males. Children from single-parent households and of lower socioeconomic status are more common targets, as are children with physical, neurological, or emotional problems; black males are overrepresented in all those situations.... Although age of onset of abuse is similar across genders, girls are generally abused up to an older age, as boys begin to fend off abusers sooner. Actual or attempted intercourse is more common with boys, as is extrafamilial abuse. (Hernandez, Lodico, \& DiClemente, 1993, p. 594)

Among racially diverse groups of men, young Black males experienced statutory rape, sexual coercion, and sexual manipulation more than other groups (French, Tilghman, \& Malebranche, 2015). These experiences of sexual trauma often cause Black males to endorse negative racial and sexual stereotypes of their female abusers (French, Teti, Suh, \& Serafin, 2019). Like other male victims of sexual assault, the experience of rape and child sexual abuse is linked to depression, increased sexual risk taking, and increased risk for intimate partner violence perpetration and victimization, as well as hatred toward the abuser's group (Curry and Utley, 2018; Denov, 2004; Lewis, McElroy, Harlaar, \& Runyan, 2016; Turner, Taillieu, Cheung, \& Afifi, 2017).

How we perceive the risk of sexual violence that Black males experience dictates how we conceptualize and interpret their realities. Our inability to recognize the data on and stories of sexual violence against Black males over the course of their lives harms this group. Our hesitancy to acknowledge that the violence and aggression we associate with Black masculinity originates in their survival of sexual violence and trauma comes from a deeply held and societally reinforced racist misandry that believes Black males are actually the cause of societal sexual violence, not its victims. As scholars, we need to focus on the vulnerability of Black males to sexual violence and how this experience of trauma influences the attitudes and behaviors of this group. We must move beyond the focus on the sex/gender of the perpetrator to an understanding of the dangers confronting the victims-why Black males are more vulnerable to sexual assault and violence than are the men and women of other racial groups.

Burke's focus on the victims of sexual violence makes her analysis more open than those coming out of the academy. Burke insisted that men and boys cannot and should not be excluded from \#MeToo's recognition of victims. She explained:

It should never have become an "us and them" thing.... \#MeToo has been popular because of the moment we're in, but it's not really a women's movement: it's a movement for all survivors of sexual violence. Yes, women are the drivers because so many are victims, but we can't erase the boys who spoke up about Kevin Spacey or the millions of men who have been subjected to sexual violence, too.... Men are not the enemy and we have to be clear about that. (Walden, 2018, paras. 7-8) 
Unfortunately, Burke's words often fall on deaf ears since the driving force behind \#MeToo has primarily focused on high-profile celebrity cases and causes and not the disproportionate suffering and sexual violence of minority men and women or girls and boys. Burke has been adamantly critical of the framing of \#MeToo as being exclusive of male victims. In August 2018, she wrote:

I've said repeatedly that the \#metooMVMT is for all of us, including these brave young men who are now coming forward. It will continue to be jarring when we hear the names of some of our faves connected to sexual violence unless we shift from talking about individuals $\ldots$ and begin to talk about power. Sexual violence is about power and privilege. That doesn't change if the perpetrator is your favorite actress, activist or professor of any gender. And we won't shift the culture unless we get serious about shifting these false narratives. (Burke, 2018a)

By focusing on power, Burke insisted on recognizing perpetrators of sexual violence regardless of gender. By focusing on the experiences of victims, Burke reconfigures much of the feminist paradigm determined by male perpetration and patriarchy to consider the consequences of trauma and pain carried by victims. According to Burke (2018b),

Part of the work of the Me Too Movement is about the restoration of that humanity for survivors, because the violence doesn't end with the act. The violence is also the trauma that we hold after the act. Remember, trauma halts possibility. It serves to impede, stagnate, confuse and kill. So our work rethinks how we deal with trauma.

As such, the victims of sexual violence must be understood beyond the act of sexual violence. They must be understood as living with trauma that outlasts the event of violation. Black men and boys remain untreated and uncared for throughout their lives. They live with the pain of sexual violence and rape, and then are denied the compassion necessary for them to heal and not become burdened by their scars.

\section{Black male vulnerability and the struggle to be a Black male victim of sexual violence}

The rape of Black males in the United States has a long but unacknowledged history in contemporary theories of sexual violence. Since slavery, Black men have been used as sex toys and pornographic actors for White men who forced Black men to rape women for enjoyment (Foster, 2011; Aidoo, 2018). White men often sodomized Black males as punishment for not completing assigned tasks or for the pleasure of slaveowners who used Black male bodies to fulfill their sexual desires (Woodard, 2014). While the rapes of Black males by White men during slavery were sometimes made known to the public through legal proceedings, the rape of Black men and boys by White women were clandestine affairs. Black men were raped by White women during slavery as a form of sexual experimentation and offered a means of sexual release not possible within the puritanical norms of 19th-century America (Foster, 2011, p. 462). The rape of Black men and boys by White Americans during slavery, encoded a common occurrence, made sexual violence against Black males invisible.

Because Black males were thought to be savage hypersexual rapists, there was no way for the world to see them as victims of rape. The threat Whites claimed Black males posed as the rapists made it impossible to imagine Black males as being victims of rape. 
Black men and boys were able to be sexually violated for centuries without a mention of this victimization in history books or among theorists (Curry, 2017, 2018a). During Jim Crow segregation, this stratagem became even more obvious as White women used the myth of the Black rapist to hide their rape of young Black males who worked in their homes (Curry, 2018a). Among historians and theorists alike, Black male victimization to racism and sexual violence is interpreted primarily through the act of lynching. Because Black men are imagined throughout history and within theory by their proximity to the rapist, our most general conceptualizations of Black males deny their vulnerability to rape. The fear that White society has of Black men and boys is not merely a sociohistorical stereotype but the foundation of disciplinary method and gender theory (Curry, 2017).

This history of scapegoating Black men for rape and deviance is the major obstacle to seeing Black men as victims (Curry, 2018b). In the 1950s, White sociologists documented the sexual debut of Black boys between the ages of seven and nine with much older adolescent girls (Kardiner and Ovesey, 1951). Rather than interpreting the rape of these young boys as victims of undeserved violence, Kardiner and Ovesey maintained the early sexual intercourse of Black boys was due to their innate hypersexuality and deviance. Even within their own race, Black male bodies historically were exploited as objects of others' sexual desire, yet Black boys are not thought to be able to be victimized regularly as children. Despite recent studies that suggested Black boys have sexual intercourse at earlier ages than other populations (between the ages of 12 to 14 and 9 to 12), Black males are not thought of as being reared in highly sexualized environments or endangered by early sexual experiences that fall within our current understanding of statutory rape (Biello, Ickovics, \& Niccolai, 2013; Cavazos-Rehg, Krauss, \& Spitznagel, 2009). As Black and male, there is an erroneous view that Black male children are men and are invulnerable to rape and sexual assault.

This historical stereotype is so strong that for many people in the United States, be they Black or White, Black men are denied being able to be victims of other people's sexually predatory acts. The association of Black males with violent threats is so strong that multiple psychologists have observed that simply seeing a Black male body or hearing a Black male's name triggers aggression, threat construction, and a fight-or-flight response among some Whites (Goff, 2008; Holbrook, Fessler, \& Navarrete, 2016). This is not a problem of recognition whereby Black men are not simply seen as suffering at the hands of others. This is an ontological problem-a problem of definition and social being-wherein the very being, the kind of existence of Black men and boys, does not allow them to be harmed or affected by the actions of others. Black men have no characterological defense against the violent tropes launched against them in the United States. As dehumanized entities, Black males are thought to be capable of any and every atrocity against women, children, and society imaginable (Curry, 2017, pp. 167-168). Overshadowed by the specter of violence and deviance and death, many people do not believe Black men can be victims of rape. Black men are insatiable. They want sex; if they did not want it, they are (or should be) capable of fending off an attacker. Hypermasculinity, hypersexuality, and fear converge to make it inconceivable that these big brutes could not or would not harm whomever they believed to be capable of sexually violating them. 
Crews's description of the cult of masculinity and toxic masculinity did little to offer an understanding of Black male trauma that considers the rates of victimization and violence Black males are exposed to within society. In a recent interview on Bravo's Watch What Happens Live, Crews was asked whose support surprised him the most after he spoke out about his sexual abuse. He said:

I have to say this: the people that surprised me the most were Black women. Black men did not want any part of it. All my support came from Black women, straight up. And that's kind of wild. It shocked me. It shocked my family. I thought, here I am as a Black man saying some things that we've all been through, and a lot of guys [were] just like, "Man, you're weak. You're sorry. You should have hit him. You should have knocked him out. You should have did all this stuff." Black women were like, "No, no. It doesn't work like that." And I was shocked at the split within my own community. It was deep. (Boone, 2019, paras. 3-8)

Crews suggested that Black men had no interest in his victimization at the hands of Venit, despite the overwhelming number of Black male victims of sexual assault and violence in the United States. In no interview has Crews attempted to situate the silencing of Black males specifically as a potential explanation for what he perceived as a lack of support. While Crews admitted earlier in the interview that he received "no support initially" from the Black community, he failed to interrogate the responses of Black men beyond what he perceived as their toxic masculinity and aggressive response to his sexual violation. Crews has since apologized to Black men for saying they did not care about his assault and admitted if it had not happened to him he would have remained ignorant of male sexual victims (Crews, 2019c). While Crews acknowledged that he "mistakenly drew attention to the worst examples and should have remained focused on the best of who we are" (Crews, 2019d), the caricatures of Black men he perpetuated reinforced stereotypes of Black men held by popular Black feminist critics and White society more broadly.

Is anger not a legitimate response by Black men to sexual assault? Crews suggested in his testimony to Congress that he too felt anger but did not defend himself against Venit because of what the media and the White world would say about a Black man beating up a White man. Was his initial impulse to attack Venit his toxicity? No. It is a natural and justifiable response. Whereas our society often accepts a woman's right to defend herself against sexual violence, Crews and many of his supporters place an additional burden on Black male victims. Because our society believes that Black men are violent, it is now the responsibility of Black men not to fulfill this stereotype by finding other ways to address sexual assault against their bodies. What Crews shows us in his hesitancy to defend himself through violence, as well as the lack of empathy for his victimization as a Black man, is that he in fact recognizes that his masculinity is not like the dominant White masculinity. He recognizes that his ability to be recognized as a victim of sexual violence is intimately tied to how the White public sees him, not whether he actually suffered a sexual assault. Crews knows he has to be respectable and peaceful enough for the U.S. public not to be afraid of him. In doing so, he distances himself from the experience and marginalization that other Black men who do not have the opportunity to be recognized as victims of sexual violence, or anything else, endure.

For more than a century, racist caricatures of hypersexuality, deviance, and danger have obscured Black men's sexual victimization and rape. Black males are the only 
group throughout the history of the United States who have endured "Negrophilic and Negrophobic relations simultaneously-as both the victim of rape and the supposed perpetrator of rape" (Curry, 2018a, p. 149). The Black male has been raped throughout history but has been denied being seen as a victim of rape because he is feared to be the rapist. The fear of being seen as a Black beast, the insatiable sexual savage, a violent animal, was so powerful that it stopped Crews from defending himself from sexual assault. Crews understood at a visceral level that if he defended himself from sexual violence, he would become the epitome of violence-the dangerous Nigger. As a Black man, Crews had to decide which act of violence he could endure: to be sexually assaulted and groped by a White man in public in front of his wife or judged by White America as the savage Nigger who attacked a White man. For many Black men, this is a far too common and impossible choice.

Crews's victimization at the hands of a White man unsettles our habitual thinking about sexual violence. To say that racism and desire work simultaneously toward Black male bodies in the form of an aggressive homoeroticism by White men and dangerous sexual aggression by White women disrupts the illusion of danger Black male bodies pose. When we consider the mutilation and violence inflicted on Black men, we now have to consider that what we are reflecting on is libidinal outrage, the frustration one has in not being able to completely possess the body of the despised Nigger, and how that frustration manifests itself throughout history as lynching, the castration of Black men, and the sodomization of Black male bodies. By extricating sexual vulnerability from the history under which Black men and boys suffer, we contribute to the thinking that holds the only thing that can hurt Black men are bullets-that their primary suffering is rooted in death (Curry, 2014, 2016, 2017).

Crews's victimization poses a problem and a complication in the traditional feminist narrative of patriarchy. Whereas female victims of sexual assault and harassment are viewed as vulnerable because all women are vulnerable to and thought to be victimized by the patriarchal power of men (who are thought to be a class of perpetrators and violent), male victims are thought to be situational. Male victims may exist, but they are victims of particular individuals, not victimized historically by a class of perpetrators or offenders who make their position as subordinate men in the society vulnerable to sexual violence. Black Male studies scholars hold that racialized men are the primary targets of White patriarchal rage (Curry, 2017, 2018b; Miller, 1991, 1994) and cannot benefit from hegemonic male power. Within these racialized patriarchies, racialized men are subject to extreme forms of violence, such as lynching, murder, and rape. Crews's victimization is an opportunity to rethink how Black men exist as a racialized class of men who have always been particularly vulnerable to sexual violence within patriarchy. The issue is not that Crews was sexually assaulted by a White man. The issue is that Terry could be assaulted by a White man and no one in the United States would believe that he was actually a victim of sexual assault or rape because he is a Black man.

\section{Conclusion}

Terry Crews's story provides an opportunity to rethink how we formulate cultural narratives of sexual violence and rape that exclude the experiences of Black men. While it 
is of the utmost importance to respect the story of Crews and his experience of marginalization in society as a Black man and as a Black male victim within \#MeToo, it is equally important for scholars, activists, and survivors to interrogate how we come to understand and interpret the vulnerability of Black men and boys to sexual violence in this society through his victimization. The question posed to \#MeToo by Crews is not whether this moment can recognize the stories of Black male victims without apology. The question the victimization of Crews poses is whether the history of sexual vulnerability presented to the world as the terror of patriarchy actually captures the reality of rape and sexual violence against Black men in this society. \#MeToo has not begun to address the history of rape against Black men in the United States and how stereotypes of Black men as hypermasculine misogynists and rapists ensure the erasure of Black men's sexual vulnerability and victimization. \#MeToo ignores the role that homoeroticism and sexual fetishization have played in the rape and sexual victimization of Black men and boys throughout history while asserting that the presumed hypermasculinity of Black men makes them more likely to be rapists and threats to women.

To accept that a Black man is just as likely as any woman-and more likely than a White woman-to be sexually victimized destroys the long-standing belief that rape is particular to the female body. This is a particularly controversial position, because it is the uniqueness of rape as gendered violence toward women that imparts a particular moral force. Black males continue to endure sexual violence at rates similar to women but are refused recognition as victims of this violence. If we confront this neglect of Black male pain, we quickly realize that it is our fear of Black men that prevents us from seeing their reality. Black men's caricatures as rapists and brutes have limited the ways through which we theorize their existence and the violence to which they are subject in the real world. Theory needs them to be boogeymen, so academics and activists imagine them as such (Curry, 2018b).

To accept that Black men are victims of rape because of racism and that some of these rapists are women or other men would mean not only the collapse of the gender analytic that makes patriarchy the sole cause of all rape and sexual violence against women but a reorientation of feminist theory such that the moral force of the claim that condemns all men for their capacity to harm women is lessened. While it is perhaps not debilitating to say some men are victims of rape by other men, it is threatening to the presumed operation of gender within Western patriarchal societies to say that all Black men suffer under the threat of rape because of their inferior status in the United States as racialized men. The violence and sexual victimization of Black men and boys concretized by Crews stands opposite to the valorization of the White woman victim and demands for us to think about the structural and cultural arrangements of patriarchy that continue to make the rape of Black men and boys a deliberately neglected chapter in the history of rape and sexual assault in the United States.

\section{References}

Aidoo, L. (2018). Slavery unseen: Sex, power, and violence in Brazilian history. Durham, NC: Duke University Press.

Arceneaux, M. (2018, August 28). If we want men to be a part of \#MeToo, we have to stop gendering the movement. Glamour. Retrieved from https://www.glamour.com/story/me-too-movementmen-sexual-assault-survivors?verso=true 
Biello, K., Ickovics, J., \& Niccolai, L. (2013). Racial differences in age at first sexual intercourse: Residential racial segregation and the Black-White disparity among U.S. adolescents. Public Health Reports, 128(1), 23-32. doi:10.1177/00333549131282S103

Black, M. C., Basile, K. C., Breiding, M. J., Smith, S. G., Walters, M. L., Merrick, M. T., Chen, J., \& Stevens, M. R. (2011). The National Intimate Partner and Sexual Violence Survey (NISVS): 2010 summary report. Atlanta, GA: National Center for Injury Prevention and Control, Centers for Disease Control and Prevention.

Boone, K. (2019, January 15). We're not surprised! Terry Crews say Black women supported him the most after his sexual assault. Essence. Retrieved from https://www.essence.com/celebrity/ terry-crews-black-women-supported-him-after-sexual-assault/

Bowen, A. (2018, August 21). Amid Asia Argento accusation, what a \#MeToo moment can be like for male victims. Chicago Tribune. Retrieved from http://www.chicagotribune.com/lifestyles/sc-fam-asia-argento-men-me-too-0828-story.html\#

Brownmiller, S. (1975). Against our will: Men, women, and rape. New York, NY: Fawcett.

Bump, B. (2018, April 17). Male victims deserve their own \#MeToo movement, state officials say. Times Union. Retrieved from https://www.timesunion.com/news/article/Male-victims-deservetheir-own-MeToo-movement-12842188.php

Burke, T. (2018b, November). MeToo is a movement, not a moment [Video file]. Retrieved from https://www.ted.com/talks/tarana_burke_me_too_is_a_movement_not_a_moment

Burke, T. [TaranaBurke]. (2018a, August 20). I've said repeatedly that the \#MeTooMVMT is for all of us, including these brave young men who are now coming forward. It will continue to be jarring when we hear the names of some of our faves connected to sexual ... [Tweet]. Retrieved from https://twitter.com/taranaburke/status/1031498206260150272

Carbon, S. B. (2012, January 6). An updated definition of rape. Washington, DC: U.S. Department of Justice. Retrieved from https://www.justice.gov/archives/opa/blog/updated-definition-rape

Cavazos-Rehg, P., Krauss, M. J., \& Spitznagel, E. L. (2009). Age of sexual debut among U.S. adolescents. Contraception, 80(2), 158-162. doi:10.1016/j.contraception.2009.02.014

Chandler, M. A. (2018, April 8). Men account for nearly 1 in 5 complaints of workplace sexual harassment with the EEOC. Washington Post. Retrieved from https://www.washingtonpost. $\mathrm{com} /$ local/social-issues/men-account-for-nearly-1-in-5-complaints-of-workplace-sexual-harassment-with-the-eeoc/2018/04/08/4f7a2572-3372-11e8-94fa-32d48460b955_story.html

Chang, M., \& O’Neill, G. (2018, January 15). Should Aziz Ansari's career be ruined by these sexual misconduct allegations? Elle Australia. Retrieved from https://www.elle.com.au/culture/ should-aziz-ansari-lose-his-career-15572

Clark, T. (2018, September 6). The Hollywood agent Terry Crews accused of sexual assault is stepping down. Business Insider. Retrieved from https://www.businessinsider.com/wme-agent-terrycrews-accused-of-sexual-assault-will-step-down-from-wme-2018-9

Cohen, C. (2014). Male rape is a feminist issue: Feminism, governmentality, and male rape. New York, NY: Palgrave MacMillan.

Cooper, F. R. (2005). Against bipolar Black masculinity: Intersectionality, assimilation, identity performance, and hierarchy. University of California Davis Law Review, 39(3), 853-904.

Crary, D. (2018, April 19). \#MeToo movement "furthers my loneliness," male sexual assault victims say. Global News. Retrieved from https:/globalnews.ca/news/4154420/male-sexual-assault-victimsmetoo-left-behind/

Crews, T. [TerryCrews]. (2017a, October 10). "240 lbs. Black Man stomps out Hollywood Honcho" would be the headline the next day. (5/cont.) [Tweet]. Retrieved from https://twitter. com/terrycrews/status/917838656500506625

Crews, T. [TerryCrews]. (2017b, October 10). My wife n I were at a Hollywood function last year $\mathrm{n}$ a high level Hollywood executive came over 2 me and groped my privates [Tweet]. Retrieved from https://twitter.com/terrycrews/status/917838500061253632.

Crews, T. [TerryCrews]. (2019a, January 25). My father. And toxicity was when he was punching my mother in the face. Next question? [Tweet]. Retrieved from https://twitter.com/terrycrews/ status/1088958538066448384 
Crews, T. [TerryCrews]. (2019b, January 25). This article is THOUGHT-PROVOKING Straight Black Men Are the White People of Black People https://verysmartbrothas.theroot.com/straightblack ... via @verysmartbros [Tweet]. Retrieved from https://twitter.com/terrycrews/status/ 1088802324535902209

Crews, T. [TerryCrews]. (2019d, March 12). I mistakenly drew attention to the worst examples and should have remained focused on the best of who we are [Tweet]. Retrieved from https://twitter.com/terrycrews/status/1105491277573840897

Crews. T. [TerryCrews]. (2019c, March 12). I'd like to also apologize to the Black men that were hurt by my comments regarding a lack of support regarding my sexual assault [Tweet]. Retrieved from https://twitter.com/terrycrews/status/1105491274419777536

Curry, T. J. (2014). Michael Brown and the need for a genre study of Black male death and dying. Theory and Event, 17(Suppl. 3). Retrieved from https://muse.jhu.edu/article/559369

Curry, T. J. (2016). Eschatological dilemmas: The problem of studying the Black male only as the deaths that result from anti-Black racism. In J. Lee \& F. L. Hord (Eds.), I am because we are (pp. 479-499). Amherst: University of Massachusetts Press.

Curry, T. J. (2017). The man-not: Race, class, genre, and the dilemmas of Black manhood. Philadelphia, PA: Temple University Press.

Curry, T. J. (2018a). He's a rapist, even when he's not: Richard Wright's account of the Black male vulnerability in the raping of Willie McGee. In J. Gordon \& C. E. Zirakzadeh (Eds.), The politics of Richard Wright: Perspectives on resistance (pp. 132-154). Lexington: University of Kentucky Press.

Curry, T. J. (2018b). Killing boogeymen: Phallicism and the misandric mischaracterizations of Black males in theory. Res Philosophica, 95(2), 235-272. doi:10.11612/resphil.1612

Curry, T. J., \& Curry, G. (2018). Taking it to the people: Translating empirical findings about Black men and Black families through a Black public philosophy. Dewey Studies, 2(1), 42-71.

Curry, T. J., \& Utley, E. (2018). She touched me: Five snapshots of adult sexual violations of African American boys. Kennedy Institute of Ethics Journal, 28(2), 205-241. doi:10.1353/ken. 2018.0014

Denov, M. S. (2004). The long-term effects of child sexual abuse by female perpetrators: A qualitative study of male and female victims. Journal of Interpersonal Violence, 19(10), 1137-1156. doi:10.1177/0886260504269093

Foster, T. (2011). The sexual abuse of Black men under American slavery. Journal of the History of Sexuality, 20(3), 445-464. doi:10.1353/sex.2011.0059

French, B. H., Teti, M., Suh, H. A., \& Serafin, M. R. (2019). A path analysis of racially diverse men's sexual victimization, risk-taking, and attitudes. Psychology of Men and Masculinities, 20(1), 1-11. doi:10.1037/men0000159

French, B. H., Tilghman, J., \& Malebranche, D. (2015). Sexual coercion context and psychosocial correlates among diverse males. Psychology of Men and Masculinity, 16(1), 42-53. doi:10.1037/ a0035915

Garfield, G. (2010). Through our eyes: African American men's experiences of race, gender, and violence. Piscataway, NJ: Rutgers University Press.

Goff, P. A. (2008). Not yet human: Implicit knowledge, historical dehumanization, and contemporary consequences. Journal of Personality and Social Psychology, 94(2), 292-306. doi:10.1037/ 0022-3514.94.2.292

Groden, C. (2014, September 8). Why is it so hard to determine exactly how many women are raped each year? New Republic. Retrieved from https://newrepublic.com/article/119364/cdcsreport-one-five-women-raped-other-statistics-disagree

Haider, M. (2019, January 23). The next step in \#MeToo is for men to reckon with their male fragility. Slate. Retrieved from https://slate.com/news-and-politics/2019/01/men-male-fragilitymetoo-progress.html

Hernandez, J. T., Lodico, M., \& DiClemente, R. J. (1993). The effects of child abuse and race on risk taking in male adolescence. Journal of the National Medical Association, 85(5), 593-597. 
Hohendorff, J. V., Habigzang, L. F., \& Koller, S. H. (2017). “A boy, being a victim, nobody really buys that, you know?": Dynamics of sexual violence against boys. Child Abuse and Neglect, 70, 53-64. doi:10.1016/j.chiabu.2017.05.008

Holbrook, C., Fessler, D., \& Navarrete, C. D. (2016). Looming large: Racial stereotypes illuminate dual adaptation for representing threat versus prestige as physical size. Evolution and Human Behavior, 37(1), 67-78. doi:10.1016/j.evolhumbehav.2015.08.004

hooks, b. (2004). We real cool: Black men and masculinity. New York, NY: Routledge.

Kardiner, A., and Ovesey, L. (1951). The mark of oppression: A psychosocial study of the American Negro. New York, NY: W. W. Norton.

Kelly, E. (2018, June 27). Terry Crews explains why he didn't fight back during alleged sexual assault in emotional speech to U.S. Senate. Metro. Retrieved from https://metro.co.uk/2018/06/ 27/terry-crews-explains-didnt-fight-back-alleged-sexual-assault-emotional-speech-us-senate-7663513/

Klee, M. (2018, June 7). Brendan Fraser's \#MeToo story is why more male victims don't speak out. MEL Magazine. Retrieved from https://melmagazine.com/en-us/story/brendan-frasersmetoo-story-is-why-more-male-victims-dont-speak-out

Koss, M. P. (1993). Rape: Scope, impact, interventions, and public policy responses. American Psychologist, 48(10), 1062-1069. doi:10.1037/0003-066X.48.10.1062

Levin, S. (2017, October 31). Hollywood actors speak of "rampant" problem of male abusers targeting men. The Guardian. Retrieved from https:/www.theguardian.com/world/2017/oct/31/ hollywood-male-abusers-boys-gay-men-kevin-spacey

Lewis, T., McElroy, E., Harlaar, N., \& Runyan, D. (2016). Does the impact of child sexual abuse differ from maltreatment but non-sexually abused children? A prospective examination of the impact of child sexual abuse on internalizing and externalizing behavior problems. Child Abuse and Neglect, 51, 31-40. doi:10.1016/j.chiabu.2015.11.016

Lynch, J. P. (1996). Review: Clarifying divergent estimates of rape from two national surveys. Public Opinion Quarterly, 60(3), 410-430.

Mack, A. N., \& McCann, B. J. (2018). Critiquing state and gendered violence in the age of \#MeToo. Quarterly Journal of Speech, 104(3), 329-344. doi:10.1080/00335630.2018.1479144

MacKinnon, C. A. (1979). Sexual harassment of working women: A case of sexual discrimination. New Haven, CT: Yale University Press.

Messer, L., \& Ghebremedhin, S. (2018, March 8). Authorities reject Terry Crews' sexual assault case. $A B C$ News. Retrieved from https://abcnews.go.com/GMA/Culture/authorities-reject-terrycrews-sexual-assault-case/story?id $=53595423$

Milano, A. [Alyssa_Milano]. (2017, October 15). If you've been sexually harassed or assaulted write "me too" as a reply to this tweet [Tweet]. Retrieved from https://twitter.com/alyssa_ milano/status/919659438700670976

Miller, E. (1991). Men at risk. Kingston: Jamaica Publishing House.

Miller, E. (1994). Marginalization of the Black male: Insights from the teaching profession. Kingston, Jamaica: Canoe Press.

Moore, A. [tonetalks]. (2018, March 9). How \#MeToo forgot Terry Crews-Why this is about power not gender-Dash Radio [Video file]. Retrieved from https://www.youtube.com/ watch?v=aaH01ahXZwg

Norton, P. (2017, October 24). The problem with men saying \#MeToo. The Good Men Project. Retrieved from https://goodmenproject.com/featured-content/problem-men-saying-metoo-lbkr/

Patten, D. (2018, January 20). Terry Crews talks Sundance relevance, today's respect rally, and changing America. Deadline. Retrieved from https://deadline.com/2018/01/womens-march-sundanceterry-crews-frederick-douglass-sorry-to-bother-you-1202263753/

Perry, D. M. (2018, October 19). \#HimToo should be a conversation about male victims of sexual assault. Pacific Standard. Retrieved from https://psmag.com/social-justice/himtoo-and-male-victimsof-sexual-assault

Santi, C. (2018, June 27). Terry Crews condemns "toxic masculinity" during sexual assault testimony. Ebony. Retrieved from https://www.ebony.com/entertainment-culture/terry-crews-toxic-masculinitysexual-assault-testimony 
Santiago, C., \& Criss, D. (2017, October 17). An activist, a little girl, and the heartbreaking origin of "Me Too." CNN. Retrieved from https:/www.cnn.com/2017/10/17/us/me-too-tarana-burkeorigin-trnd/index.html

Schroeder, J. (2018, August 23). Yes, men can be sexually assaulted. Gender stereotypes make it hard to talk about. Vox. Retrieved from https://www.vox.com/first-person/2018/8/23/17772712/ asia-argento-news-jimmy-bennett

Smith, S. G., Chen, J., Basile, K. C., Gilbert, L. K., Merrick, M. T., Patel, N., ... Jang, A. (2017). The National Intimate Partner and Sexual Violence Survey (NISVS): 2010-2012 State Report. Atlanta, GA: National Center for Injury Prevention and Control, Centers for Disease Control and Prevention. Retrieved from https://www.cdc.gov/violenceprevention/pdf/NISVS-State ReportBook.pdf

Stemple, L., Flores, A., \& Meyer, I. (2017). Sexual victimization perpetrated by women: Federal data reveal surprising prevalence. Aggression and Violent Behavior, 34, 302-311. doi:10.1016/j. avb.2016.09.007

Stemple, L., \& Meyer, I. (2014). The sexual victimization of men in America: New data challenge old assumptions. American Journal of Public Health, 104(6), e19-e26. doi:10.2105/AJPH.2014. 301946

Turner, S., Taillieu, T., Cheung, K., \& Afifi, T. O. (2017). The relationship between childhood sexual abuse and mental health outcomes among males from a nationally representative United States sample. Child Abuse and Neglect, 66, 64-72. doi:10.1016/j.chiabu.2017.01.018

Walden, C. (2018, March 9). \#MeToo founder has mixed feelings about how it unfolded. The Age. Retrieved from https://www.theage.com.au/lifestyle/life-and-relationships/metoo-founderhas-mixed-feelings-about-how-it-unfolded-20180309-p4z316.html

Way, K. (2018, January 13). I went on a date with Aziz Ansari. It turned into the worst night of my life. Babe. Retrieved from https://babe.net/2018/01/13/aziz-ansari-28355

Weiss, B. (2018, August 21). Asia Argento proves, once again, that women are human beings. New York Times. Retrieved from https://www.nytimes.com/2018/08/21/opinion/asia-argentoavital-ronell-weinstein.html

White, A. (2008). Ain't I a feminist? African American men speak out on fatherhood, friendship, forgiveness, and freedom. Albany: State University of New York Press.

Wolfgang, M., \& Ferracuti, F. (1967). The subculture of violence: Towards an integrated theory in criminology. Abingdon, United Kingdom: Tavistock.

Women in the World. (2018, April 14). Terry Crews: Men don't see women as "all the way human" [Video file]. Retrieved from https://www.youtube.com/watch?v=GibE058a4P0

Woodard, V. (2014). The delectable Negro: Human consumption and homoeroticism with U.S. slave culture. New York: New York University Press.

Young, D. (2017, September 9). Straight Black men are the White people of Black people. The Root. Retrieved from https://verysmartbrothas.theroot.com/straight-black-men-are-the-whitepeople-of-black-people-1814157214 